\title{
Embedding Microbial Fuel Cells into the Vertical Flow Constructed Wetland Enhanced Denitrogenation and Water Purification
}

\author{
Qi Liu, Boxun Zhou, Shici Zhang, Dan Xu, Rong Pan, Shibin Xia* \\ School of Resource and Environmental Engineering, Wuhan University of Technology, Wuhan, Hubei, P.R. China
}

Received: 23 January 2018

Accepted: 16 April 2018

\begin{abstract}
Constructed wetlands have been extensively applied for treating drinking water sources and other water bodies that are not severely polluted due to their low construction and operation costs. In this regard, microbial fuel cells (MFC) could potentially achieve both energy generation and wastewater purification, though the construction cost is high. Based on the bio-electrochemical theory, a novel device of the integrated vertical flow constructed wetland (IVCW) embedded with MFC (IVCW-MFC) was designed and built for treating the slightly-polluted source waters with relatively high nitrogen and low carbon, where denitrification was usually hindered. Both water purification performance and electrical characteristics were examined in this system. It was observed that the maximum output voltage and power density could reach $777 \mathrm{mV}$ and $8.05 \mathrm{~mW} \cdot \mathrm{m}^{-2}$, respectively, when the external resistance was $6000 \Omega$. With a better denitrification effect, the system exhibited a more effective removal of chemical oxygen demand (COD) and nitrate. The maximum efficiency of total nitrogen (TN) removal was as high as $97.35 \%$, while the average removal efficiency was around $70 \%$, even with a load of TN, $3.3 \mathrm{mg} / \mathrm{L}$ on average, in the influent. Furthermore, the macrophytes grew normally in the constructed wetland without any influence.
\end{abstract}

Keywords: vertical flow constructed wetland, microbial fuel cell (MFC), slightly polluted source water, denitrification, power generation

\section{Introduction}

At present, the sewage of low $\mathrm{COD} / \mathrm{N}$ ratio is a challenge in the traditional sewage treatment technology [1]. In the conventional biological nitrificationdenitrification process, the carbon content of low $\mathrm{COD} / \mathrm{N}$ ratio sewage cannot support complete denitrification,

*e-mail: xiashibin@126.com resulting in the need for an external carbon source [2]. However, constructed wetland $(\mathrm{CW})$ is an economically viable option for treating the wastewater of low concentrations currently. In constructed wetland ecosystems, contaminants are removed through physical adsorption, chemical degradation, and bio absorption. Therefore, the constructed wetland wastewater ecological restoration technology is featured with environmental friendliness in removing pollutants [3-5]. However, the existing studies on constructed wetlands have shown 
Table 1 . Water quality parameters $(\mathrm{mg} / \mathrm{L})$ of simulated wastewater influent.

\begin{tabular}{|c|c|c|c|c|c|c|}
\hline Parameters & COD & $\mathrm{TP}$ & $\mathrm{TN}$ & $\mathrm{NH}_{4}^{+}-\mathrm{N}$ & $\mathrm{NO}_{3}^{-}-\mathrm{N}$ & $\mathrm{NO}_{2}^{-}-\mathrm{N}$ \\
\hline Average & 15.5 & 0.17 & 3.3 & 0.85 & 1.6 & 1.11 \\
\hline Range & $10.6 \sim 20.4$ & $0.02 \sim 0.40$ & $2.18 \sim 6.74$ & $0.123 \sim 1.245$ & $1.036 \sim 3.326$ & $0.107 \sim 1.921$ \\
\hline
\end{tabular}

that the removal rate of $\mathrm{TN}$ varied from $40 \%$ to $55 \%$ with the fluctuation of load from 250 to $630 \mathrm{~g} \mathrm{~N} \cdot \mathrm{m}^{-2} \cdot \mathrm{yr}^{-1}$ [6]. Due to the limited removal of TN by constructed wetlands, it is imperative to study the improvement of $\mathrm{TN}$ removal rate. With dual advantages in wastewater treatment and power generation, microbial fuel cells (MFC) have been studied to improve and increase their output power [7-12]. However, the application of MFC in the pilot scale is extremely limited and the output power has encountered bottlenecks. Therefore, some MFC-based composite application technologies emerged successively. Compared with pure MFC, these composite technologies show greater practical value [13].

Based on biological electrochemical principles, this study attempted to evaluate the constructed wetland as a viable microenvironment for employing a microbial electrochemical catalyst to harness power. The wetlandmicrobial fuel cell composite system of pollutant degradation was determined through pilot-scale experiments, which laid a foundation for promoting large-scale practical application.

\section{Material and Methods}

Simulated wastewater was employed in the experiments, and the water quality parameters are shown in Table. 1. Two sets of integrated verticalflow constructed wetland (IVCW), which had been successfully running for a year, were adopted in this study. The electrodes were placed into one set to build MFC and the other set to serve as the control group. Composed of a down-flow chamber and an up-flow chamber $(50 \times 50 \times 100 \mathrm{~cm})$ made with PVC panels, the IVCW system was filled with quartz sands as substrates. The down-flow chamber and up-flow chamber were connected to each other by the pores in the middle of the PVC panel (Fig. 1). Moreover, the down-flow and

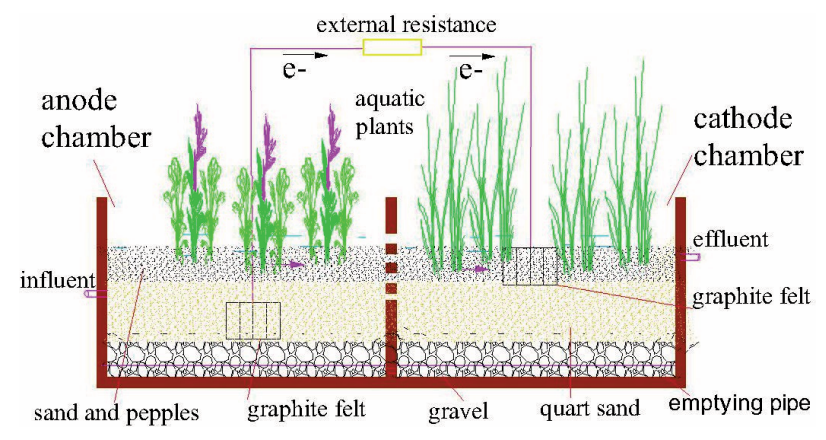

Fig. 1 Schematic diagram of IVCW-MFC test device. up-flow chambers were planted with Canna sp. and Acorus calamus. The pipes with pores were placed at the top of the chamber substrates to distribute the influent evenly in the down-flow chamber and collect the treated water in the up-flow chamber to guarantee a stable water flow in the whole constructed wetlands.

An MFC device was integrated into the IVCW system with electrode materials. The down-flow chamber was used as an anodic chamber and the upflow one as a cathode, and graphite panels $(400 \times 200$ $\times 3 \mathrm{~mm}$ ) were applied as electrode materials. Both sides of the anode and cathode were fixed with the inlet and the outlet, with the electrode socket sitting on top of the device. Copper wires sealed with epoxy sealant were utilized to connect the electrodes and the load resistance box (0 9999 $\Omega)$.

Substrate degradation and current output parameters were used to evaluate the performance of the IVCWMFC system. MFC output voltages were measured by a digital multimeter once an hour, and current generation was monitored for polarization at various external resistances (1000-6000 $\Omega)$ [14].

Power (mW) was derived from $\mathrm{P}=\mathrm{VI}$ equation, where $\mathrm{V}$ and I referr to the voltage and current. Current density I $\left(\mathrm{mA} \cdot \mathrm{m}^{-2}\right)$ and power density $\mathrm{P}\left(\mathrm{mW} \cdot \mathrm{m}^{-2}\right)$ were calculated with the function of anodic surface area. Circuit current (mA) was calculated based on Ohm's Law $\mathrm{I}=\mathrm{V} / \mathrm{R}$, where $\mathrm{R}(\Omega)$ means external resistance and $\mathrm{V}(\mathrm{mV})$ is the voltage across the external resistor.

Wastewater purification was assessed by monitoring parameters of chemical oxygen demand $\left(\mathrm{COD}_{\mathrm{Cr}}\right)$, ammonium $\left(\mathrm{NH}_{4}^{+}-\mathrm{N}\right)$, total nitrogen $(\mathrm{TN})$, nitrate $\left(\mathrm{NO}_{3}^{-}-\mathrm{N}\right)$, nitrite $\left(\mathrm{NO}_{2}^{-}-\mathrm{N}\right)$, and total phosphorus (TP) of influent and effluent, according to the Water and Wastewater Monitoring and Analysis Methods of China ( $4^{\text {th }}$ edition). The treatment performance was evaluated by measuring the removal rates of these substrates.

\section{Results and Discussion}

\section{Electrical Characteristics}

\section{Polarization Curve and Resistance Selection}

Polarization performance of the system was monitored during the stable phase of operation under each loading condition. The MFC output voltage presented a similar trend to different external resistances ranging 1000-6000 $\Omega$ over the time course during the daytime (Fig. 2). However, the output voltage value became closer to the open circuit voltage as the external 


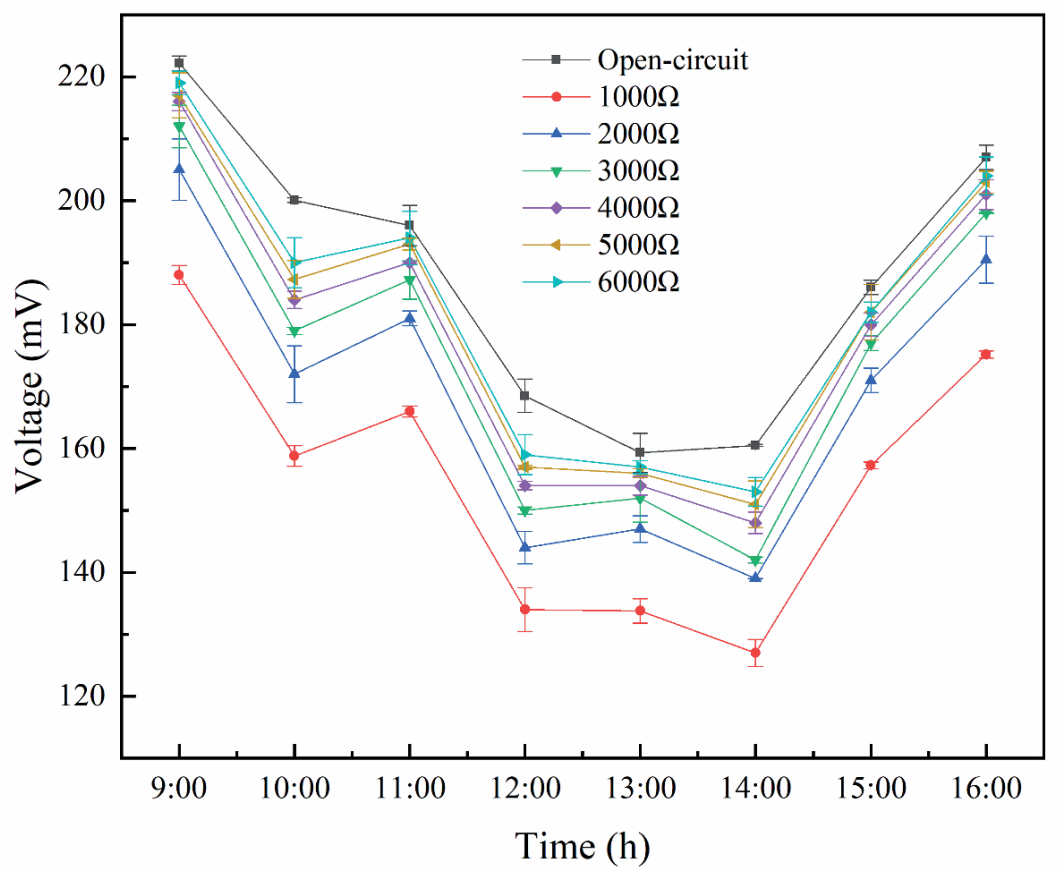

Fig. 2. Voltage changes of IVCW-MFC with external resistors.

resistance increased. When the external resistance reached $6000 \Omega$, the output voltage was almost equal to the open circuit voltage.

With respect to power output, the current density gradually decreased with the increase of the resistance, and the maximum power density was observed at the resistance of $6000 \Omega$. As the electronic transmission to the cathode was blocked by resistance, the resistor became a limiting factor of MFC when the resistance value was more than $6000 \Omega$. On the other hand, proton transfer was a main limiting factor of MFC operation when the resistance was less than $6000 \Omega$. Low resistance allowed for a higher electron flow in the microbial fuel cell circuit, resulting in a potential drop - especially at lower resistances despite of higher power density. Therefore, choosing an appropriate resistance was the key to improve the yield of MFC electrical properties. The resistor with the resistance of $6000 \Omega$ was chosen as the MFC running external resistor based on the experimental results. The polarization and power density curve showed that the maximum output voltage, $777 \mathrm{mV}$, and the maximum power density, $8.05 \mathrm{~mW} \cdot \mathrm{m}^{-2}$, were observed at the designed resistance of $6000 \Omega$ during the stable phase of the operation (Fig. 3a).

\section{Long-Term Electricity Generation Capacities}

The daily average external battery voltage of IVCW-MFC during the 103 days of operation showed that the initial voltage of the system could reach $284 \mathrm{mV}$. The maximum output voltage of $777 \mathrm{mV}$ was achieved on 56d (Fig. 3b). The stable high voltage lasted for about $14 \mathrm{~d}$ and the voltage gradually was reduced after $70 \mathrm{~d}$. The voltage decreased to $32 \mathrm{mV}$ after $76 \mathrm{~d}$ and then the voltage began to rise again slowly. The system voltage was stabilized at $300 \mathrm{mV}$ for a long period.

\section{Diurnal Electrical Changes}

IVCW-MFC power generation changes within a day (08:00-24:00) were evaluated after the system was stabilized and the voltage was recorded every half hour. The output voltage was relatively stable between 08:00 and 12:00, stabilized at $628 \mathrm{mV}$ from 12:00 to 14:00, dropped to $285 \mathrm{mV}$ at 14:00, then rose again and reached $600 \mathrm{mV}$ at 22:00. The voltage was stabilized around $400 \mathrm{mV}$ (Fig. 3c). The drop of output voltage between 10:00-16:00 was mainly attributed to the active plant photosynthesis during that time, which affected the microbial electricity production.

\section{Effects of Temperature on Electricity Production}

Recently, many researchers have investigated the microbiology, electrodes, configuration, matrix, operating conditions, and electrochemical properties of MFC and have discovered that the influence of non-biological factors on the production of electricity performance is greater than that of biological factors, although the micro-organism was the core of MFC [15]the adaptation time (during 3 weeks of operation. Therefore, the impact of temperature on the electricity production system is worthy of attention.

The devices were operated from July 1 to September 30,2011 , with the ambient temperature between $23-27^{\circ} \mathrm{C}$ and the voltage between $600 \mathrm{mV}-750 \mathrm{mV}$. Microbial 
a)

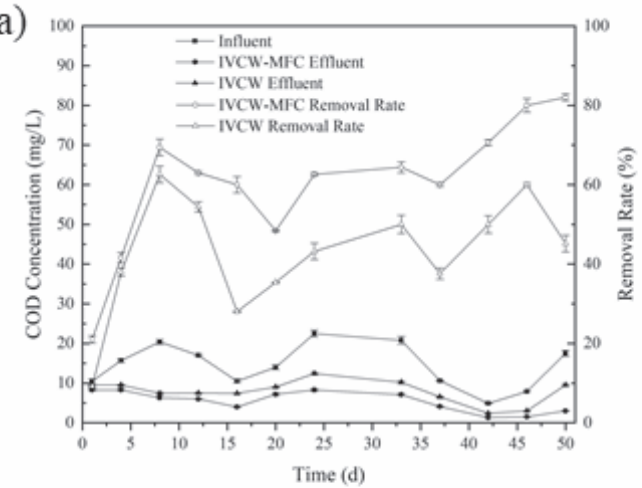

c)

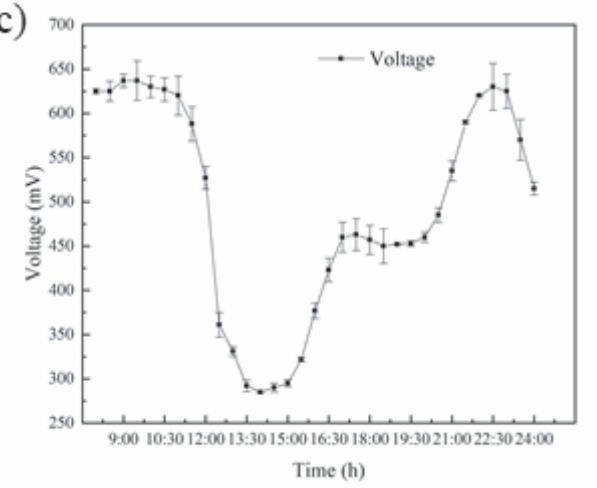

b)

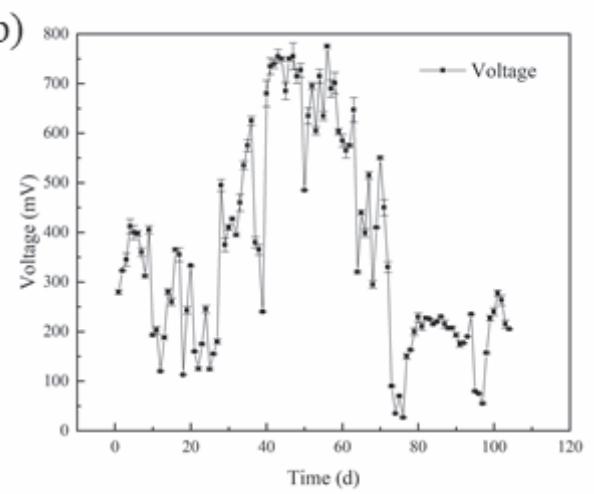

d)

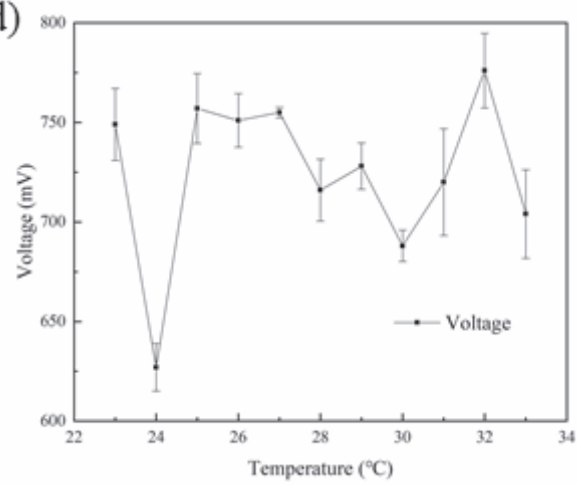

Fig. 3. Physical parameters changes of IVCW-MFC: a) Polarization and power density curves of IVCW-MFC; b) Electricity changes during long-term operation of IVCW-MFC; c) Electrical changes in one day during long-term operation of IVCW-MFC; d) Relationship between the power production of IVCW-MFC and temperature.

activity was increased as the temperature rose, which was profitable for improving power generation (Fig. 3d).

\section{Performance of Water Purification}

IVCW-MFC exhibited a higher COD removal efficiency than IVCW (Fig. 4a). The influent COD ranged from $10.6 \mathrm{mg} / \mathrm{L}$ to $20.4 \mathrm{mg} / \mathrm{L}$, with an average of $15.5 \mathrm{mg} / \mathrm{L}$. The average COD removal efficiency of IVCW-MFC was $60 \%$ (with the effluent COD of $6.2 \mathrm{mg} / \mathrm{L}$ ), while the average COD removal efficiency of IVCW control was $51.6 \%$ (with the effluent COD of $7.5 \mathrm{mg} / \mathrm{L})$.

The ammonia nitrogen removing curve during the operation was shown in Fig. 4(b). When the influent ammonia nitrogen $\left(\mathrm{NH}_{4}^{+}-\mathrm{N}\right)$ concentration was 0.85 $\mathrm{mg} / \mathrm{L}$, the average effluent $\mathrm{NH}_{4}^{+}-\mathrm{N}$ was $0.42 \mathrm{mg} / \mathrm{L}$ with the removal efficiency of $51 \%$, and the average IVCW effluent $\mathrm{NH}_{4}^{+}-\mathrm{N}$ was $0.48 \mathrm{mg} / \mathrm{L}$ with the removal efficiency of $43.5 \%$.

Fig. 4c) showed the removal efficiency of $\mathrm{NO}_{3}$ $-\mathrm{N}$ during the stable operation stage of the devices. A higher removal efficiency, $81 \%$, was observed in the IVCW-MFC operation (with the effluent $\mathrm{NO}_{3}^{-}-\mathrm{N}$ of $0.3 \mathrm{mg} / \mathrm{L}$ ) and only $53 \%$ in the IVCW operation (with the effluent $\mathrm{NO}_{3}^{-}-\mathrm{N}$ of $0.75 \mathrm{mg} / \mathrm{L}$ ), as the average influent $\mathrm{NO}_{3}^{-}-\mathrm{N}$ was $1.6 \mathrm{mg} / \mathrm{L}$.
The average effluent $\mathrm{NO}_{2}^{-}-\mathrm{N}$ of IVCW-MFC was $0.61 \mathrm{mg} / \mathrm{L}$ and the average removal efficiency was $45 \%$ when the average influent $\mathrm{NO}_{2}^{-}-\mathrm{N}$ was $1.11 \mathrm{mg} / \mathrm{L}$ (Fig. 4d). The average effluent $\mathrm{NO}_{2}^{-}-\mathrm{N}$ of IVCW was $0.57 \mathrm{mg} / \mathrm{L}$ and the average removal efficiency was $48.6 \%$. These results revealed that there was no $\mathrm{NO}_{2}^{-}-\mathrm{N}$ accumulation in the device, and $\mathrm{NO}_{2}^{-}-\mathrm{N}$ reduction was much more thorough.

Fig. 4e) showed the removal rate of TN during the stable operation of the devices. It was shown that the removal efficiency of $\mathrm{TN}$ increased stably with the increase of running time and the removal efficiency reached $97.35 \%$ on $50 \mathrm{~d}$ as the influent average TN was $3.3 \mathrm{mg} / \mathrm{L}$. The average TN removal efficiency of IVCWMFC was $70 \%$ (with the effluent TN of $1.0 \mathrm{mg} / \mathrm{L}$ ) and the average TN removal efficiency of IVCW was $42 \%$ (effluent TN of $1.9 \mathrm{mg} / \mathrm{L}$ ).

Thus, the denitrification of IVCW-MFC was more obvious than that of IVCW. Biological denitrification was the main method of nitrogen removal in constructed wetlands. However, the total nitrogen removal efficiency of IVCW was usually not high, and carbon source was insufficient in the slightly polluted source water. In this regard, the denitrogenating function of IVCW could be enhanced with the embedding of MFC.

Fig. 4f) presented the total phosphorus removal efficiency during the stable operation of the device. 
a)

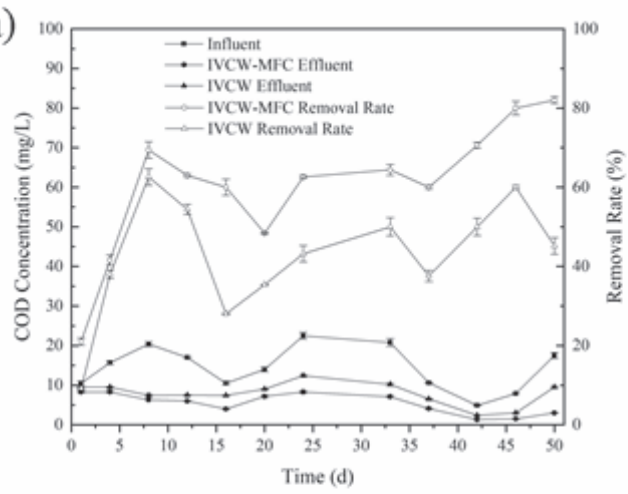

c)

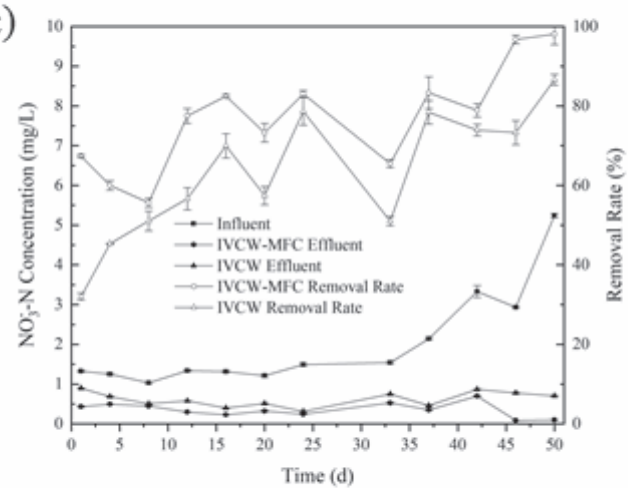

e)

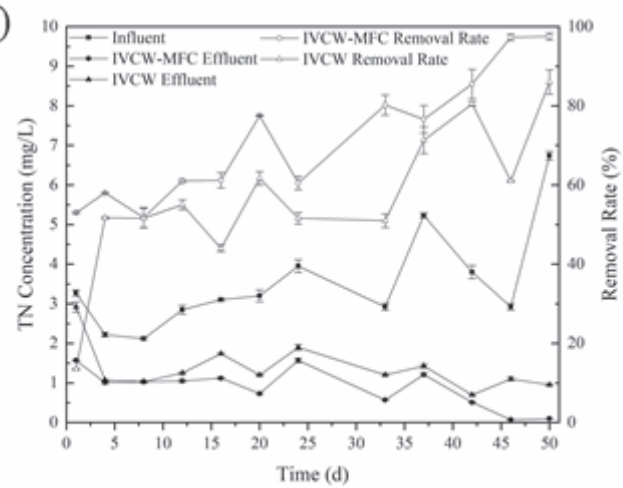

b)

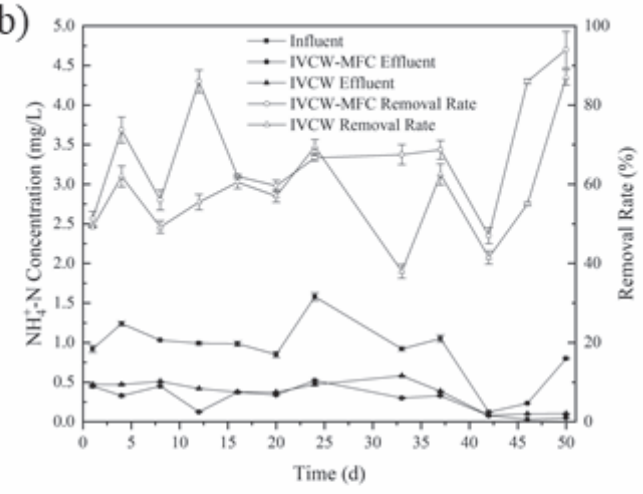

d)

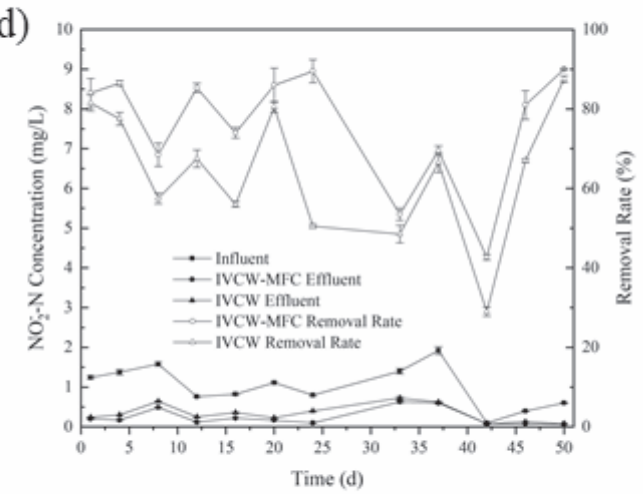

f)

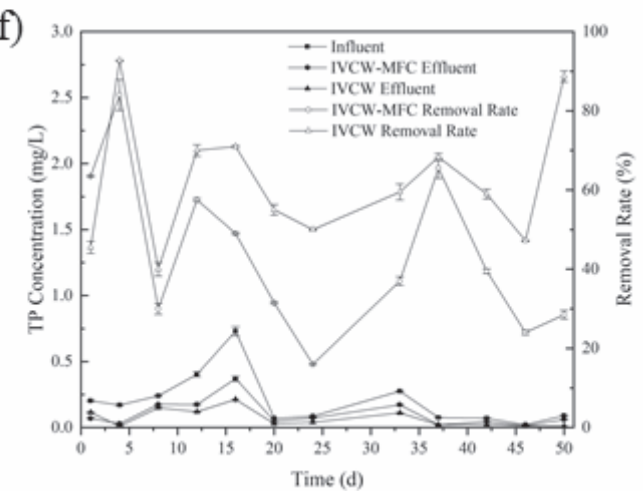

Fig. 4. Removal of pollutant indicators in IVCW-MFC and IVCW during operation: a) COD removal; b) $\mathrm{NH}_{4}^{+}-\mathrm{N}$ removal; c) $\mathrm{NO}_{3}^{-}-\mathrm{N}$ removal; d) $\mathrm{NO}_{2}^{-}-\mathrm{N}$ removal; e) TN removal; and f) TP removal.

The average effluent TP of IVCW-MFC was $0.12 \mathrm{mg} / \mathrm{L}$ with a removal efficiency of $29.4 \%$, while the average effluent TP of IVCW was $0.06 \mathrm{mg} / 1$ with a removal efficiency of $64.7 \%$, as the influent average TP was $0.17 \mathrm{mg} / \mathrm{L}$. The effluent TP concentration of IVCWMFC was higher than IVCW, which needs to be further investigated.

In addition, constructed wetlands could rely on the synergistic effects of the physical, chemical and biological processes of the system, i.e., via the filtration, adsorption, precipitation, ion exchange, plants absorption, and microbial decomposition for the purification of wastewater.

From the above data, it could be observed that both IVCW-MFC and IVCW presented good treatment effects on $\mathrm{COD}_{\mathrm{Cr}}, \mathrm{NH}_{4}^{+}-\mathrm{N}, \mathrm{TN}, \mathrm{NO}_{3}^{-}-\mathrm{N}, \mathrm{NO}_{2}^{-} \mathrm{N}$, and TP. The capability of IVCW-MFC was higher than that of IVCW in some indicators. MFC utilized the organic matter in the sewage to produce electricity, resulting in higher COD removal and denitrogenation as well as phosphate release.

\section{Growth of Wetland Plants}

The power generation in the system embedded with microbial fuel cells did not affect the normal growth of plants during the trials of 3 months. In IVCW-MFC, plant growth monitoring showed that the Canna shoots increased from the initial $50 \mathrm{~cm}$ to $160 \mathrm{~cm}$ and Acorus from $37 \mathrm{~cm}$ up to $178 \mathrm{~cm}$. In IVCW, Canna shoots 
increased from $46 \mathrm{~cm}$ to $156 \mathrm{~cm}$ and Acorus from $30 \mathrm{~cm}$ to $162 \mathrm{~cm}$.

\section{Conclusions}

In this MFC-IVCW system, the maximum output voltage, $777 \mathrm{mV}$, and the maximum power density, $8.05 \mathrm{~mW} \cdot \mathrm{m}^{-2}$, were achieved when external resistance reached $6000 \Omega$. This system exhibited effective removal of COD and nitrates from the wastewater, and strong denitrogenation, with the maximum removal efficiency of $97.35 \%$ and the average removal efficiency of $70 \%$ when the average $\mathrm{TN}$ of influent was $3.3 \mathrm{mg} / \mathrm{L}$. The aquatic plants grew normally in the system without being affected by the installed MFC devices. In conclusion, simultaneous wastewater treatment and bioelectricity generation seem feasible by embedding microbial fuel cell devices into constructed wetlands. Sewage purification efficiency was satisfactory, especially in terms of nitrogen removal. The result shows that this IVCW-MFC system is ecologically friendly and has great potential for further development and broad applications.

\section{Acknowledgements}

This research was supported by the Fueling Shale Gas Environmental Exploration Technology of National Science and Technology Special Project (grant No. 2016ZX05060) and the Demonstration of Integrated Management of Rocky Desertification and Enhancement of Ecological Service Function in Karst Peak-Cluster Depression (grant No. 2016YFC0502400). I would like to express my gratitude to my friends in Group FineWeather.

\section{Conflict of Interest}

The authors declare no conflict of interest.

\section{References}

1. ZHI W., JI G. Quantitative response relationships between nitrogen transformation rates and nitrogen functional genes in a tidal flow constructed wetland under $\mathrm{C} / \mathrm{N}$ ratio constraints. Water Research, 64, 32, 2014.

2. BERNET N., DELGENES N., AKUNNA J.C., DELGENES J.P., MOLETTA R. Combined anaerobic - aerobic SBR for the treatment of piggery wastewater. Water Research, 34 (2), 611, 2000.

3. GORITO A.M., RIBEIRO A.R., ALMEIDA C.M.R., SILVA A.M.T. A review on the application of constructed wetlands for the removal of priority substances and contaminants of emerging concern listed in recently launched EU legislation. Environmental Pollution, 227, 428, 2017

4. ILYAS H., MASIH I. The performance of the intensified constructed wetlands for organic matter and nitrogen removal: A review. Journal of Environmental Management, 198, 372, 2017.

5. VYMAZAL J. The Use of Constructed Wetlands for Nitrogen Removal from Agricultural Drainage: a Review. Scientia Agriculturae Bohemica, 48 (2), 82, 2017.

6. ZHANG D.Q., JINADASA K.B.S.N., GERSBERG R.M., LIU Y., NG W.J., TAN S.K. Application of constructed wetlands for wastewater treatment in developing countries - A review of recent developments (2000-2013). Journal of Environmental Management, 141, 116, 2014.

7. XU L., ZHAO Y., DOHERTY L., HU Y., HAO X. The integrated processes for wastewater treatment based on the principle of microbial fuel cells: A review. Critical Reviews in Environmental Science and Technology, 46 (1), 60, 2016.

8. JANICEK A., FAN Y., LIU H. Design of microbial fuel cells for practical application: a review and analysis of scale-up studies. Biofuels, 5 (1), 79, 2014V

9. LI X., ABU-REESH I.M., HE Z. Development of Bioelectrochemical Systems to Promote Sustainable Agriculture. Agriculture, 5 (3), 367, 2015.

10. YOSHIZAWA T., MIYAHARA M., KOUZUMA A., WATANABE K. Conversion of activated-sludge reactors to microbial fuel cells for wastewater treatment coupled to electricity generation. Journal of Bioscience and Bioengineering, 118 (5), 533, 2014.

11. EL MEKAWY A., SRIKANTH S., BAJRACHARYA S., HEGAB H.M., NIGAM P.S., SINGH A., PANT D. Food and agricultural wastes as substrates for bioelectrochemical system (BES): The synchronized recovery of sustainable energy and waste treatment. Food Research International, 73, 213, 2015

12. PANT D., SINGH A., BOGAERT G.V., OLSEN S.I., NIGAM P.S., DIELS L., VANBROEKHOVEN K. Bioelectrochemical systems (BES) for sustainable energy production and product recovery from organic wastes and industrial wastewaters. RSC Advances, 2 (4), 1248, 2012.

13. ADELAJA O., KESHAVARZ T., KYAZZE G. Treatment of phenanthrene and benzene using microbial fuel cells operated continuously for possible in situ and ex situ applications. International Biodeterioration \& Biodegradation, 116, 91, 2017.

14. HELDER M., STRIK D.P.B.T.B., HAMELERS H.V.M., KUHN A.J., BLOK C., BUISMAN C.J.N. Concurrent bioelectricity and biomass production in three Plant-Microbial Fuel Cells using Spartina anglica, Arundinella anomala and Arundo donax. Bioresource Technology, 101 (10), 3541, 2010.

15. BAKONYI P., KOÓK L., KELLER E., BÉLAFIBAKÓ K., RÓZSENBERSZKI T., SARATALE G.D., NEMESTÓTHY N. Development of bioelectrochemical systems using various biogas fermenter effluents as inocula and municipal waste liquor as adapting substrate. Bioresource Technology, 259, 75, 2018. 